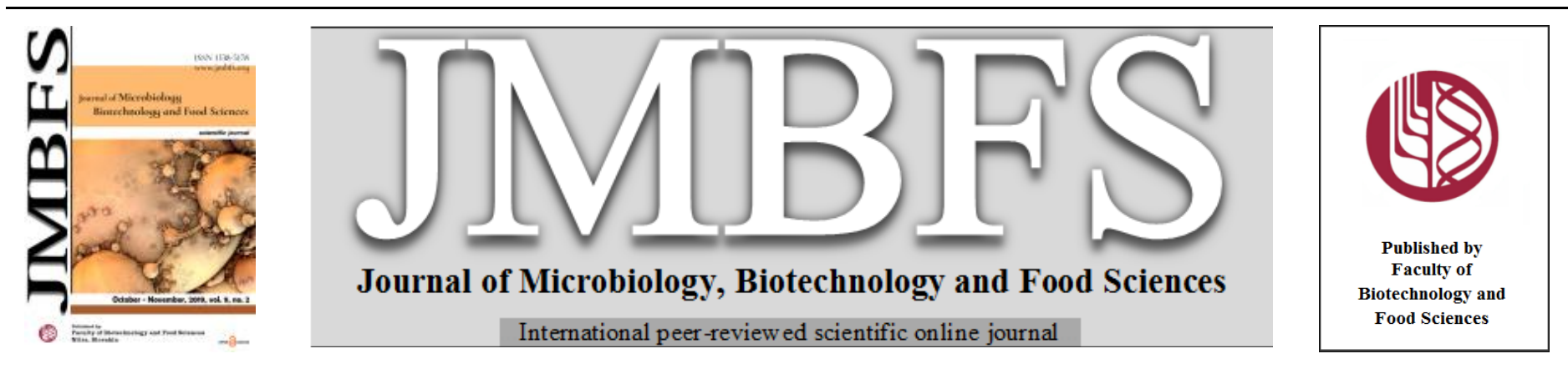

\title{
BIODEGRADATION OF BISPHENOL A DURING SUBMERGED CULTIVATION OF TRAMETES VERSICOLOR
}

\author{
Mariya Brazkova*l, Galena Angelova ${ }^{1}$, Albert Krastanov ${ }^{1}$ \\ Address(es): Mariya Brazkova \\ ${ }^{1}$ University of Food Technology, Department of Biotechnology, 26 Maritza Blvd, Plovdiv, Bulgaria.
}

*Corresponding author: brazkova.m@gmail.com

doi: 10.15414/jmbfs.2019.9.2.204-207

\section{ARTICLE INFO}

Received 13. 12. 2018

Revised 26. 3. 2019

Accepted 26. 3. 2019

Published 1. 10. 2019

Short communication

open 2 access

\begin{abstract}
Bisphenol A is a persistent chemical, which is widely distributed in the environment despite its short half-life. The continuous release of BPA may cause a chronical exposition of the organisms during sensitive life stages. The chemical possesses not only endocrine disrupting functions but also by oxidative stress may cause damage to the liver cells. In this study the ability of Trametes versicolor 8979 to degrade Bisphenol A during submerged cultivation was exanimated. The chemical was introduced to the medium in 500ppm concentration and the laccase and $\mathrm{MnP}$ activities, as well as the residual BPA concentration were monitored. The strain was able to remove completely Bisphenol A from the medium in 6 hours.
\end{abstract}

Keywords: Trametes versicolor, Bisphenol A, Laccase, Biodegradation

\section{INTRODUCTION}

Bisphenol A (4,4'-isopropylidene-2-diphenol) is a synthetic compound that is formed by the condensation of phenol with acetone. It is widely used in the production of multitude of products including building materials, electronic components, long-lasting resistant to heat food containers and many widely used plastic products (Staples et al., 1998, Jiao et al., 2008, Björnsdotter et al. 2017). The annual production of BPA in 2016 was 8 million metric tons and its assumed to hit over 10 million metric tons by 2022 (Bisphenol, 2016). BPA polymerization leads to formation of compounds which could be hydrolyzed under aggressive conditions such as high temperatures and extreme $\mathrm{pH}$ values, thus causing BPA leaching into the environment. (Chouhan et al., 2014). The average daily BPA exposure was evaluated to be from 0.48 to $1.6 \mu \mathrm{g} / \mathrm{kg}$ body mass/day, for adults and children, respectively (Flint et al., 2012).

Bisphenol A is a persistent chemical, which is widely distributed in the environment despite its short half-life. (Oehlmann et al., 2009). Release can occur during chemical manufacture, transport, and processing. Post-consumer releases are primarily via effluent discharge from municipal wastewater treatment plants, leaching from landfills, combustion of domestic waste, and the natural breakdown of plastics in the environment (Crain et al., 2007; Kang et al., 2007; Kinney et al., 2006; Sidhu et al., 2005; US Environmental Protection Agency, 2010). Due to BPA environmental ubiquity and the wide usage of compounds analogues, the possibility of chronical rates of exposure of the organisms escalates. Also the exposure could happen in sensitive life stages such as infant development (Flint et al., 2012). BPA is known to possess endocrine disrupting activity and could cause damage of liver cells with the mechanisms of oxidative stress. Studies show the possibility of BPA to modulate the immune activity, also demonstrate the possession of mutagenic and teratogenic activity on eukaryotic cells (Michalowicz, 2014). BPA exposure in early stage of development leads to increased risk of developing mammary and prostate cancers (Seachrist et al., 2016, Noszczyńska and Piotrowska-Seget, 2018). The exposition of the fetus, infants and young children to BPA is considered to be especially harmful due to the lack of information regarding hormones activity, synthesis and elimination. Higher levels of anxiety, hyperactivity, depression and conduct problems could be linked with BPA exposure during childhood development (Rykowska and Wasiak, 2006, Braun et al., 2009, Ejaredar et al., 2017).

The growing problem on Bisphenol A release into the environment and their toxic effects on humans and wildlife require the elaboration of new technological solutions able to minimize or eliminate the environmental exposure (Cabana et al., 2007). Some of the successfully developed methods for BPA removal are based on biological or electrochemical oxidation, ozonation and biodegradation (Kang et al., 2006, Yang et al., 2013). The usage of microorganisms for BPA removal is promising method regarding waters. Biodegradation techniques allow not only the removal of persistent pollutants but also are considered promising in the field of toxicological risk reduction not only of BPA but for other bisphenols as well (Sakai et al., 2007, Danzl et al., 2009, Zhang et al., 2013, Noszczyńska and Piotrowska-Seget, 2018). Several bacteria distributed in waste water treatment plant as well as in river water are capable to easily degrade BPA. Usually the degradation process is initiated not by single microorganism but by whole microbial communities. Still degradation studies are focused more on the isolation and characterization of single microorganisms and their biodegradation abilities. However, the practical application of such experiments is limited due to a lack of efficacy at high concentrations (Xiong et al., 2017b, Noszczyńska and Piotrowska-Seget, 2018).

In recent years the ability of white-rot fungi to degrade harmful chemicals has been widely investigated. Those basidiomycetes possess lignin-degrading activity presented by the enzymes laccase, manganese-dependent peroxidase (MnP) and lignin peroxidase (LiP). It has been reported that $\mathrm{MnP}$ and laccase from Pleurotus osrteatus are able to degrade BPA and have the ability to ameliorate or eliminate the estrogenic activity of BPA (Brugnari et al, 2018; Hirano et al., 2000, Lee $\boldsymbol{e t}$ al., 2005). Moreover, studies on laccases of the basidiomycetes Trametes villosa (Fukuda et al., 2001), Coriolopsis polyzona (Cabana et al., 2007), Trametes versicolor (Kim et al., 2008; Margot et al., 2013, Zeng et al. 2017), Trametes polyzona (Chairin et al., 2013), Grifola frondosa (Nitheranont et al., 2011), as well as laccases from other basidiomycetes (Tanaka et al., 2000; Kim and Nicell, 2006), revealed the potential of these oxidative enzymes for BPA degradation. Despite the lower redox potential of laccases, they are able to oxidase non-phenolic compounds when low molecular mass mediators are present. This makes them suitable for industrial and environmental purposes (Ca ñas and Camarero, 2010; Camarero et al., 2014 Daassi et al., 2016). This study focuses on investigation of degradation ability of Trametes versicolor 8979 towards BPA during submerged cultivation in the presence of BPA.

\section{MATERIAL AND METHODS}

Fungal strain

Trametes versicolor NBIMCC\#8979 was isolated from the hills in Plovdiv, Bulgaria and deposed in the National Bank of Industrial Microorganisms and Cell Cultures, Sofia, Bulgaria. The strain was maintained on Chapek Dox agar, containing sucrose $-30 \mathrm{~g} / \mathrm{L}$; yeast extract $-5 \mathrm{~g} / \mathrm{L} ; \mathrm{NaNO}_{3}-2 \mathrm{~g} / \mathrm{L} ; \mathrm{K}_{2} \mathrm{HPO}_{4}-1 \mathrm{~g} / \mathrm{L}$; $\mathrm{MgSO}_{4}-0.5 \mathrm{~g} / \mathrm{L} ; \mathrm{KCl}-0.5 \mathrm{~g} / \mathrm{L}, \mathrm{FeSO}_{4}-0.01 \mathrm{~g} / \mathrm{L}$ and agar $-15 \mathrm{~g} / \mathrm{L}$ with final $\mathrm{pH}$ 6.5. The cell culture was grown on agar plates for 7 days, then was stored at $4{ }^{\circ} \mathrm{C}$. 


\section{Inoculum. Culture conditions. Biodegradation of BPA}

For the inoculum preparation a 7-day old plate culture was used. The inoculation was carried out with $5 \%$ spore suspension inserted to a $300 \mathrm{ml}$ Erlenmeyer flask containing $100 \mathrm{ml}$ Czapek-Dox medium containing: sucrose $-30 \mathrm{~g} / \mathrm{L}$; yeas extract $-5 \mathrm{~g} / \mathrm{L} ; \mathrm{NaNO}_{3}-2 \mathrm{~g} / \mathrm{L} ; \mathrm{K}_{2} \mathrm{HPO}_{4}-1 \mathrm{~g} / \mathrm{L} ; \mathrm{MgSO}_{4}-0.5 \mathrm{~g} / \mathrm{L} ; \mathrm{KCl}-0.5 \mathrm{~g} / \mathrm{L}$ and $\mathrm{FeSO}_{4}-0.01 \mathrm{~g} / \mathrm{L}$. The $\mathrm{pH}$ of the media was adjusted with $0.1 \mathrm{M} \mathrm{HCl}$ to 6.5 prior the sterilization. The inoculated flasks were incubated at $28{ }^{\circ} \mathrm{C}$ and $220 \mathrm{rpm}$ until the end of exponential phase of growth. Bisphenol A was added to the cultural medium in dry form in final concentration of $500 \mathrm{ppm}$ after which the incubation continues at the same conditions. The control sample contained uninoculated Chapek-Dox media and 500 ppm BPA.

Samples were taken every hour for the first 6 hours and after 24 hours. The biomass and protein concentration were determined, as well as the laccase and manganese-dependent peroxidase activity and residual Bisphenol A concentration

\section{Enzyme assays}

Laccase activity was determined using syringaldazyne as substrate. The reaction mixture contained cultural broth, $50 \mathrm{mM}$ potassium phosphate buffer $(\mathrm{pH} 4.5)$ and $0.216 \mathrm{mM}$ substrate solution in methanol. The change of absorption values at 530 $\mathrm{nm}$ was monitored at $37^{\circ} \mathrm{C}$ for 5 minutes (Ride, 1970). One unit of enzyme activity corresponds to 0.001 change in the absorbance at the reaction conditions and it is expressed in units per $\mathrm{mL}$.

The activity of the manganese-dependent peroxidase $(\mathrm{MnP})$ was determined by measuring the oxidation of Mn (II) to Mn (III) at $270 \mathrm{~nm}$. The reaction mixture contained $1.0 \mathrm{mM} \mathrm{MnSO}_{4}$ in $50 \mathrm{mM}$ sodium malonate buffer $(\mathrm{pH} 4.5)$ and the reaction was started by the addition of $0.5 \mathrm{mM} \mathrm{H} \mathrm{H}_{2} \mathrm{O}_{2}$ solution (Wariishi et al., 1989). One unit of enzyme activity is defined as the enzyme quantity required to oxidize $1 \mu \mathrm{mol}$ substrate for 1 minute at the reaction conditions.

\section{Determination residual Bisphenol A concentration}

Bisphenol A was extracted from the cultural medium by addition of an equivalent amount of acetonitrile (Merck $\mathrm{KGaA}$ ) to the sample followed by ultrasound treatment for 30 minutes. An ultrasonic bath Siel (Siel Ltd.) with a frequency of ultrasound $45 \mathrm{~Hz}$ was used. Then the sample is treated with Carrez solutions (Carrez, 1909) to remove sugars and proteins and followed by centrifugation at $6000 \mathrm{rpm}$ for 15 minutes. The precipitate was discarded and the supernatant was transferred to a pear-shaped flask and evaporated under vacuum at $40^{\circ} \mathrm{C}$ and 200 $\mathrm{rpm}$ on a rotary vacuum evaporator IKA RV10, equipped with a thermostatic water bath IKA HB 10 (IKA®-Werke GmbH\& Co.) and vacuum-pump Ilmvac (Gardner Denver Medical) until dry. The sample was resuspended in $5 \mathrm{~mL}$ acetonitrile (HPLC grade) and filtered through $0.45 \mu \mathrm{m}$ membrane filter. Aliquot of $20 \mu \mathrm{L}$ was taken for chromatographic analysis.

The HPLC determination was performed at Agilent 1200 Infinity Series equipped with UV-detector. The separation column was Zorbax Eclipse PAH with $5 \mu \mathrm{m}$ particle size and $4.6 \mathrm{~nm}$ inner diameter and $150 \mathrm{~mm}$ length. Acetonitrile (HPLC grade, Merck) was used as mobile phase at flow rate of $1 \mathrm{~mL} / \mathrm{min}$. The detection was made at $220 \mathrm{~nm}$. Each sample was injected three times and the mean was calculated.

BPA's derivatives were determined using GC Trace 3000 with TR-5MS column and single quadropole MS ISQ QD (Thermo Fisher Scientific Inc.). The sample $(1 \mu \mathrm{L})$ was injected in split mode. The oven temperatures were as follows: $3 \mathrm{~min}$ $60{ }^{\circ} \mathrm{C}$, increasing $15{ }^{\circ} \mathrm{C} / \mathrm{min}$ to $310^{\circ} \mathrm{C}$ and hold for 5 minutes. The transfer line temperature was $260{ }^{\circ} \mathrm{C}$ and $220{ }^{\circ} \mathrm{C}$ for the ion source. The flow rate of the helium, was $1 \mathrm{~mL} / \mathrm{min}, 70 \mathrm{eV}, \mathrm{m} / \mathrm{z} 35-350$.

\section{RESULTS AND DISCUSSION}

The basidiomycetes are proven to have the ability to degrade aromatic compounds due to the production of the lignin-degrading enzymatic complex. This complex plays an important role in the degradation of compounds with phenolic and polycyclic structure. Trametes versicolor 8979 produces high activities of laccase and manganese-dependent peroxidase which are two of the three enzymes, part of the lignin-degrading complex. The ability of Trametes versicolor 8979 to biodegrade bisphenol A during submerged cultivation was investigated. Laccase and manganese-dependent peroxidase activities are shown on figure 1. There is an induction of the both enzyme activities with the highest values measured at the $2^{\text {nd }}$ hours after the BPA introduction in the media for the laccase and at the $3^{\text {rd }}$ hour for the manganese-dependent peroxidase.

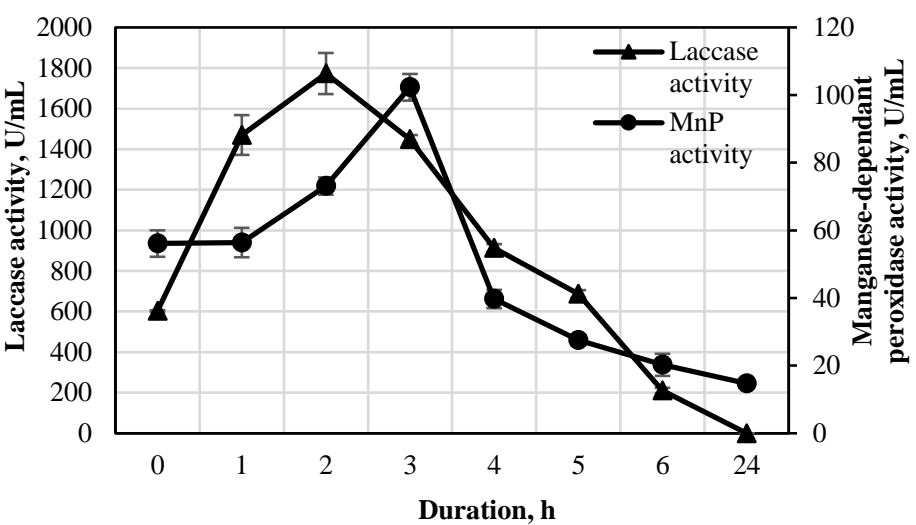

Figure 1 Enzymatic activity of laccase and manganese-dependent peroxidase during the biodegradation process

Changes in the concentration of BPA were noticeable with the analysis of the first sample at the first hour of the experiment. There was decrease in the concentration of nearly $50 \%$ after only one hour of interaction between the compound and the culture. The observed data is shown on figure 2. BPA residual concentration is below $100 \mathrm{ppm}$ after 3 hours of degradation and on the 6th our represents only $1.28 \%$ of the initial concentration. There was no BPA residues detected at the 24 th hour of the experiment.

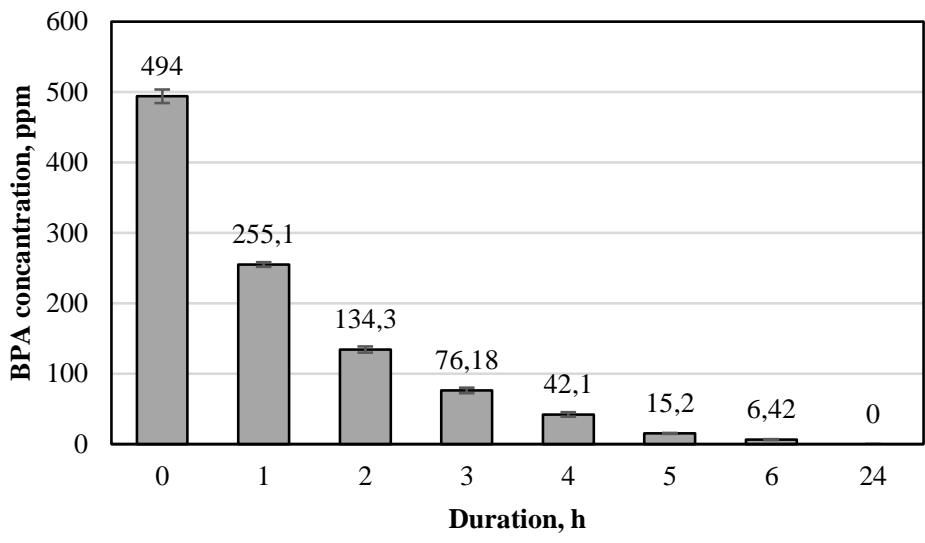

Figure 2 BPA concentration during the degradation process

Despite the limited knowledge regarding the BPA degradation with Trametes versicolor strains it is well known that the key role on this process is played by the enzymes, part of the lignin-degrading enzymatic complex. The increase of laccase activity in the first hours of the process (fig.1) correlates with intense BPA degradation (fig.2). The benzene rings in BPA structure are the main cause of the induction of laccase production during the experiment. Manganesedependent peroxidase synthesis is also induced with the addition of aromatic compounds and organic acid in the medium. This induction of the enzymatic synthesis is correlating with the results, reported by Kim et al. (2008). The laccase gene expression was examined during degradation of endocrinedisrupting chemicals including BPA. It was proven that the introduction of BPA into the medium leaded to increase of the activity of both laccase and manganesedependent peroxidase.

The BPA concentration during the process is following a classic $1^{\text {st }}$ order reaction kinetics, which allows the calculation of the rate constant and compound's halflife. The rate constant is expressed as follows:

$C_{t}=C_{o} \cdot e^{-k t}$

where $\mathrm{C}_{\mathrm{t}}$ is the BPA concentration at any time; $\mathrm{C}_{\mathrm{o}}$ is the initial concentration and $\mathrm{k}$ is the rate constant. The determination of the rate constant depends on the compound`s half-life and is expressed as follows

$k=\frac{\ln 2}{t_{1 / 2}}$

Using those equations the rate constant and the compound's half-life were determined to be $1.386 \mathrm{~h}^{-1}$ and $0.5 \mathrm{~h}$, respectively. The BPA biodegradation process is a result of the metabolization of the compound by the fungi, as well as the occurring oxidation processes by laccase and manganese-dependent 
peroxidase. In this matter a direct correlation between the enzyme activities and the biodegradation could not be made, which is visible from the figures.

The results obtained after the GC-MS analysis showed that there are no typical BPA intermediate degradation products in the analyzed samples. Also there was no residual BPA detected under the HPLC limit of detection. The degradation of Bisphenol A with Trametes versicolor strain is proven to conclude with glycerol as a final product (Daassi et al., 2016). It is possible that BPA was fully degraded and mineralized by Trametes versicolor 8979 . Such pathway where Bisphenol A degradation is full was proposed by Gasara et al. (2013). Other possibility is the formation of polymeric structure due to the laccase oxidative action which are separated during the sample filtration. In this matter it would be more accurate if the used term is removal rather than degradation of Bishenol A. In this particular experiment the biodegradation is most likely a complex process leading to full bisphenol A removal from the samples.

\section{CONCLUSION}

Bisphenol A was completely removed from the medium during submerged cultivation of Trametes versicolor 8979. The strain possess high laccase and manganese-dependent peroxidase activities which are the main reason for the fast and effective process of bisphenol A removal. Moreover, the introduction of the chemical to the medium lead to induction of the enzyme activity. Bisphenol A was almost completely removed from the reaction media for 6 hours at $28^{\circ} \mathrm{C}$ and $220 \mathrm{rpm}$.

\section{REFERENCES}

BISPHENOL A. 2016. A Global Market Overview, p. 194. Report code: CP021, Chemicals\&Materials.

BJORNSDOTTER, M.K., DE BOER, J., BALLESTEROS-GOMEZ, A. 2017. Bisphenol A and replacements in thermal paper: a review. Chemosphere 182, 691-706. https://doi.org/10.1016/j.chemosphere.2017.05.070

BRUGNARI T, PEREIRA MG, BUBNA GA, DE FREITAS EN, CONTATO AG, CORRÊA RCG, CASTOLDI R, DE SOUZA CGM, POLIZELI MLTM, BRACHT A, PERALTA RM. 2018. A highly reusable MANAE-agaroseimmobilized Pleurotus ostreatus laccase for degradation of bisphenol A. Sci Total Environ., 634:1346-1351. https://doi.org/10.1016/j.scitotenv.2018.04.051

CABANA, H., JONES, J.P., AGNATHOS, S.N. 2007. Elimination of endocrine disrupting chemicals using white rot fungi and their lignin modifying enzymes: a review. Eng. Life Sci. 7 (5), 429-456. https://doi.org/10.1002/elsc.200700017

CAMARERO S, MARTÍNEZ MJ, MARTÍNEZ AT. 2014, Understanding lignin biodegradation for the improved utilization of plant biomass in modern biorefineries. Biofuels Bioprod Biorefining.8(5):615-625. https://doi.org/10.1002/bbb.1467

CAÑAS, A.I., CAMARERO, S. 2010. Laccases and their natural mediators: Biotechnological tools for sustainable eco-friendly processes. Biotechnol. Adv 28, 694-705. https://doi.org/10.1016/j.biotechadv.2010.05.002

CARREZ M.C. 1909. Défécation du lait pour le dosage du lactose par les liqueurs cuprique. Annales de chimie analytique. 14, 187-189

CHAIRIN, T., NITHERANONT, T., WATANABE, A., ASADA, Y., KHANONGNUCH, C., LUMYONG, S. 2013. Biodegradation of Bisphenol A and Decolorization of Synthetic Dyes by Laccase from White-Rot Fungus, Trametes polyzona. Appl. Biochem. Biotechnol. 169, 539-545. https://doi.org/10.1007/s12010-012-9990-3.

CRAIN, D.A., ERIKSEN, M., IGUCHI, T., JOBLING, S., LAUFER, H., LEBLANC, G.A., GUILLETTE, L.J., 2007. An ecological assessment of bisphenol A: evidence from comparative biology. Reprod. Toxicol. 24, 225-239. https://doi.org/10.1016/j.reprotox.2007.05.008

DAASSI D., PRIETO A., ZOUARI-MECHICHI H., MARTINEZ M.J., NASRI M., MECHICHI T. 2016. Degradation of bisphenol A by different fungal laccases and identification of its degradation products. International Biodeterioration \& Biodegradation,

$110 \cdot 181-188$

https://doi.org/10.1016/j.ibiod.2016.03.017

DANZL, E., SEI, K., SODA, S., IKE, M., FUJITA, M. 2009. Biodegradation of bisphenol A, bisphenol $\mathrm{F}$ and bisphenol $\mathrm{S}$ in seawater. Int. J. Environ. Res. Public Health 6, 1472-1484. https://dx.doi.org/10.3390\%2Fijerph6041472

EJAREDAR, M., LEE, Y., ROBERTS, D.J., SAUVE, R., DEWEY, D. 2017. Bisphenol A exposure and children's behavior: A systematic review. J. Expo. Sci. Environ. Epidemiol. 27, 175-183. https://doi.org/10.1038/jes.2016.8

FLINT S., MARKLE T., THOMPSON S., WALLACE E. 2012 Bisphenol A exposure, effects and policy: A wildlife perspective. Journal of environmental Management, 104:19-34. https://doi.org/10.1016/j.jenvman.2012.03.021

FUKUDA T., UCHIDA H., TAKASHIMA Y., UWAJIMA T., KAWABATA T. AND SUZUKI M. 2001. Degradation of Bisphenol a by purified laccase from Trametes villosa. Biochem Biophys Res Commun, 284: 704-706. https://doi.org/10.1006/bbrc.2001.5021

GASSARA F., BRAR S.K., VERMA M., TYAGI R.D. 2013. Bisphenol A degradation in water by ligninolytic enzymes. Chemosphere, 92:1356-1360. https://doi.org/10.1016/j.chemosphere.2013.02.071
HIRANO T, HONDA Y, WATANABE T, KUWAHARA M. 2000. Degradation of bisphenol A by the lignin-degrading enzyme, manganese peroxidase, produced by the white-rot basidiomycete Pleurotus ostreatus., Biosci Biotechnol Biochem. Sep;64(9):1958-62. https://doi.org/10.1271/bbb.64.1958

KANG, J.H., AASI, D., KATAYAMA, Y., 2007. Bisphenol A in the aquatic environment and its endocrine-disruptive effects on aquatic organisms. Crit. Rev Toxicol. 37,607-625. https://doi.org/10.1080/10408440701493103

KANG, J.H., KONDO, F. 2002. Bisphenol a degradation by bacteria isolated from river water. Arch. Environ. Contam. Toxicol. 43, 265-269. https://doi.org/10.1007/s00244-002-1209-0

KIM Y., YEO S., SONG H.G., CHOI H.T. 2008. Enhanced expression of laccase during the degradation of endocrine disrupting chemicals in Trametes versicolor. The Journal of Microbiology, 46:402-407. https://doi.org/0.1007/s10532-009 9254-2

KIM, Y.J. NICELL, J.A. 2006. Laccase-catalyzed oxidation of bisphenol A with the aid of additives.Process Biochem. 41, 1029-1037. https://doi.org/10.1016/j.procbio.2005.11.012

KINNEY, C.A., FURLONG, E.T., ZAUGG, S.D., BURKHARDT, M.R., WERNER, S.L., CAHILL, J.D.,JORGENSEN, G.R., 2006. Survey of organic wastewater contaminants in biosolids destined for land application. Environ. Sci. Technol. 40, 7207-7215.

LAO, F.R., SUN, X.J., PANG, Z.T. 2008. Production and market analysis of bisphenol A. Chem. Indust. 26, 21-33.

LEE, S.M., KOO, B.W., CHOI, J.W., CHOI, D.H., AN, B.S., JEUNG E.B., CHOI I.G., 2005, Degradation of Bisphenol A by white rot fungi, Sterenium hirsutum and Heterobasidium insulare, and reduction of its estrogenic activity. Biol. Pharm. Bull., 28, 201-207

MARGOT, J., MAILLARD, J., ROSSI, L., BARRY, D.A., HOLLIGER, C. 2013. Influence of treatment conditions on the oxidation of micropollutants by Trametes versicolor laccase, New Biotechnol. 30, 803-813. https://doi.org/10.1016/j.nbt.2013.06.004

MICHAŁOWICZ, J., 2014. Bisphenol A - sources, toxicity and biotransformation. Environ. Toxicol. Pharmacol. 37, 738-758. https://doi.org/10.1016/j.etap.2014.02.003

NITHERANONT, $\mathrm{T}$, WATANABE, A, SUZUKI, T, KATAYAMA, T, ASADA, Y. 2011. Decolorization of synthetic dyes and biodegradation of bisphenol A by laccase from the edible mushroom Grifola frondosa. Biosci. Biotech. Bioch. 75, 1845- 1847.

NOSZCZYŃSKA, M., PIOTROWSKA-SEGET, Z., 2018, Bisphenols: application, occurrence, safety, and biodegradation mediated by bacterial communities in wastewater treatment plants and rivers. Chemosphere, 201, 214 223. https://doi.org/10.1016/j.chemosphere.2018.02.179

OEHLMANN, J., SCHULTE-OEHLMANN, U., KLOAS, W., JAGNYTSCH, O., LUTZ, I., KUSK, K.O.,WOLLENBERGER, L., SANTOS, E.M., PAULL, G.C., VAN LOOK, K.J., TYLER, C.R. 2009. A critical analysis of the biologica impacts of plasticizers on wildlife. Phil. Trans. R. Soc. B 364, 2047-2062 https://doi.org/10.1098/rstb.2008.0242

RIDE J.P. 1970. The effect of induced lignification on the resistance of wheat cell walls to fungal degradation, Physiologial Plant Pathology, 16:187-196

RYKOWSKA, I. AND WASIAK, W. 2006. Properties, threats, and methods of analysis of bisphenol a and its derivatives. Acta Chromatogr. 60-780, 21.

SAKAI, K., YAMANAKA, H., MORIYOSHI, K., OHMOTO, T., OHE, T. 2007. Biodegradation of bisphenol a and related compounds by Sphingomonas sp. strain BP-7 isolated from seawater. Biosci. Biotechnol. Biochem. 71, 51-57.

SEACHRIST, D.D., BONK, K.W., HO, S.M., PRINS, G.S., SOTO, A.M., KERI, R.A. 2016. A review of the carcinogenic potential of bisphenol A. Reprod. Toxicol. 59, 167-182. https://doi.org/10.1016/j.reprotox.2015.09.006

SIDHU, S., GULLETT, B., STRIEBICH, R., KLOSTERMAN, J., CONTRERAS, J., DEVITO, M., 2005.Endocrine disrupting chemical emissions from combustion sources: diesel particulate emissions and domestic waste open burn emissions. Atmos. Environ. 39, 801-811.

STAPLES C.A., DORN P.B., KLECKA G.M., O'BLOCK S.T., HARRIS L.R 1998. A review of the environmental fate, effects and exposures of Bisphenol A.Chreoshere. 36:2149-2173.

TANAKA, T., YAMADA, K., TONOSAKI, T., KONISHI, T., GOTO, H. TANIGUCHI, M., 2000.Enzymatic degradation of alkylphenols, bisphenol A, synthetic estrogen and phthalic ester. Water Sci. Technol. 42, 89-95.

US ENVIRONMENTAL PROTECTION AGENCY, 2010. Bisphenol A Action Plan. Washington D.C., USA.

WARIISHI, H., DUNFORD, H.B.,. MACDONALD, I.D, GOLD M.H. 1989 Manganese Peroxidase from the lignin-degrading Basidiomycette Phanerochaete chrysosporium, The journal of Biological Chemistry, Vol.264, No.6, , 3335-3340. XIONG, J., LI, G., AN, T., 2017b. The microbial degradation of 2,4,6 tribromophenol (TBP) in water/sediments interface: investigating bioaugmentation using Bacillus sp. GZT. Sci. Total Environ. 575, 573-580 http://dx.doi.org/10.1016/j.scitotenv.2016.09.017

YANG, X., TIAN, P.F., ZHANG, C., DENG, Y. QING, XU, J., GONG, J. HAN, Y.F. 2013. Au/carbon as Fenton-like catalysts for the oxidative degradation of bisphenol A. Appl. Catal. B Environ. 134-135, 145-152. 
ZENG S., ZHAO J, XIA, L. 2017, Simultaneous production of laccase and degradation of bisphenol A with Trametes versicolor cultivated on agricultural wastes, Bioprocess Biosyst Eng (2017) 40:1237-1245. https://doi.org/10.1007/s00449-017-1783-1

ZHANG, W., YIN, K., CHEN, L. 2013. Bacteria-mediated bisphenol A degradation. Appl. Microbiol. Biotechnol. 97, 5681-5689. https://doi.org/10.1007/s00253-013-4949-z 